http://dx.doi.org/10.4314/jae.v15i1.6

\title{
Climate Change Mitigation: The Role of Agriculture
}

\section{Obiora, C.J. and Madukwe, M.C}

Department of Agricultural Extension, University of Nigeria, Nsukka.

E-mail: chyjoy_obiora@yahoo.com

\begin{abstract}
The paper examined available information on the contribution of agriculture toward climate change, the effect of climate change on agriculture and the mitigation potentials of agriculture on climate change. Findings reveal that agriculture contributes to climate change majorly by the emission of methane, nitrous oxide and carbon (iv) oxide. Climate change affects agriculture through temperature rises which affect both crop and animal production, rising sea levels which causes farm land salinization and flooding and pests/diseases infestation. The mitigation potential of agriculture relies on sustainable agricultural practices which include organic farming, agro biodiversity, better land and water management practices, composting, vermicomposting, integrated pest management, cover cropping, mulching, use of bio fuel/bio energy, reduction of fertilizer use, crop rotations and soil conserving tillage which reduce soil erosion. For effective climate change mitigation through agriculture, the following recommendations were made (i) there is need for a systematic redirection of investment, funding, research and policy focus towards sustainable agriculture (ii) agricultural policies that encourage farming by subsidizing safe and sustainable farm inputs should be encouraged (iii) extension services should promote awareness-raising about sustainable agriculture and (iv) sustainable agriculture should be integrated into all level of the education system.
\end{abstract}

Key words: climate change, mitigation, agriculture, sustainable agriculture

\section{INTRODUCTION}

Agriculture is one of the oldest economic activities in the world and gainfully employs over seventy percent $(70 \%)$ of the world's population. It depends highly upon weather and climate in order to produce the food and fibre necessary to sustain human life. Not surprisingly, it is deemed to be an economic activity that is expected to be vulnerable to climate variability and change (Intergovernmental Panel on Climate Change (IPCC), 2007). Cribb (2008) noted that agricultural production, including access to food, in many African countries and regions is projected to be severely compromised by climate variability and change.

Climate is defined as the average weather conditions at a particular place over a long period of time usually a period of thirty years 
(http://en.wikipedia.org/wiki/America meterological society). Climate change refers to a statistically significant variation in either the mean state of the climate or in its variability, persisting for an extended period (typically decades or longer) while climate change mitigation refers to human intervention aimed at reducing the sources or enhancing the sinks of greenhouse gases (Intergovernmental Panel on Climate Change (IPCC), 2007).

The current scientific consensus attributes climate change to anthropogenic activities associated with increasing atmospheric concentrations of greenhouse gases (GHGs) (IPCC, 2001). Following the Industrial Revolution which began about 150 years ago, man-made activities have added significant quantities of GHGs to the atmosphere. The atmospheric concentrations of these GHGs -carbon dioxide, methane, and nitrous oxide have grown by about $31 \%, 151 \%$ and $17 \%$, respectively, between 1750 and 2000 (IPCC, 2001). Similarly, Organisation for Economic Co-operation and Development (OECD) (2008) also noted that the World GHG emissions have roughly doubled since the early 1970 s and on current policies could rise by over $70 \%$ during 2008-2050.

Agriculture is responsible for approximately fifteen percent (15\%) of all GHG emissions. Conversely, climate change now threatens to irreversibly damage natural resources on which agriculture depends. Though agriculture is a major source of greenhouse gas emissions (GHGs), it has much untapped potential to mitigate climate change (Smith, Martino, Cai, Gwary, et al. 2007). It is therefore very expedient to explore these mitigation potentials of agriculture towards climate change; hence, the following questions were raised- is agriculture contributing to climate change? Does climate change impact on agriculture? Can agriculture mitigate climate change? The paper was therefore aimed to:

(i) identify the contributions of agriculture towards climate change;

(ii) identify the effects of climate change on agriculture; and

(iii) describe the mitigation potentials of agriculture.

\section{Contributions of agriculture towards climate change}

According to the Intergovernmental Panel on Climate Change, the three main causes of the increase in greenhouse gases (GHGs) observed over the past 250 years have been fossil fuels and agricultural land use (IPCC, 2007). In the 1990s, agricultural land use was responsible for approximately $15 \%$ of all GHG emissions (Organic Consumer Association, 2008 and http://unfccc.int/resource/docs/2008/tp/08.pdf). Agricultural emissions are significant component of the developing countries GHG profile; between 1990 and 2005 agricultural emissions in developing countries increased by 32 percent (Hohenstein, 2008). According to the World Bank (2008), agriculture contributes about half of the global emissions of two of the most potent non-carbon dioxide greenhouse gases, namely: nitrous oxide and methane. Summarily, agriculture contributes to increase in greenhouse gas through the following ways: 
- Methane $(\mathrm{CH} 4)$ releases from crop and animal production (especially rice cultivation and enteric fermentation in cattle).

- Nitrous oxide (N2O) releases from fertilizer application and livestock manure.

- Carbondioxide (CO2) releases linked to fossil fuel and deforestation.

\section{Methane (CH4) releases from crop and animal production}

Agriculture is believed to account for roughly two-thirds of the total manmade methane $\left(\mathrm{CH}_{4}\right)$ emissions; mainly from paddy rice fields, burning of biomass and ruminant animal production (enteric fermentation and animal waste treatment). The cultivation of paddy rice promotes the anaerobic decomposition of plant wastes that remain after harvest and these lead to large emissions of methane. The primary on-farm sources of methane emissions also include enteric fermentation from ruminant livestock like cattle, sheep and goats. Enteric fermentation is a natural process that occurs in the digestive systems of animals such as cattle, sheep and goats. Feed quality and feed intake influence the level of methane emissions. As much as 7 percent of an animal's feed can be lost as $\mathrm{CH}_{4}$, so feedlot operators who increase animal digestive efficiency will save feed costs and decrease methane emissions (Glantz, Gommes, and Ramasamy 2009 and World Resources Institute (WRI), 2007). Options for increasing efficiency include increasing the daily percentage of highly digestible feed and correcting nutrient deficiencies in livestock diets. Inaddition, manure management also affects methane emissions. Methane is also produced by the anaerobic decomposition of manure. Dairy cattle and swine contribute about 85 percent of the methane emissions (Glantz, Gommes, and Ramasamy 2009).

\section{Nitrous oxide (N2O) releases from fertilizer application and livestock manure}

$\mathrm{N}_{2} \mathrm{O}$ comes from two main sources-livestock manure and chemical fertilizers (Organic Consumer Association, 2008 and Glantz, et al., 2009). $\mathrm{N}_{2} \mathrm{O}$ is released when bacteria interact with ammonia. Therefore, to reduce $\mathrm{N}_{2} \mathrm{O}$ emissions, farmers must decrease either direct emissions of $\mathrm{N}_{2} \mathrm{O}$ or the amount of ammonia produced during normal agricultural processes. In animal production, large amounts of ammonia are produced when urea and livestock manure break down in water or slurry. Even greater emissions come from field operations, with the applications of nitrogen fertilizer and related cropping practices. The doubling of GHG production during the last 35 years was associated with a 6.9 fold increase in nitrogen fertilization, a 3.5 fold increase in phosphorus fertilization and a 1.7 fold increase in irrigated land (Food and Agriculture Organization (FAO), 2008). The large increase in the use of nitrogenous fertilizer for the production of high nitrogen consuming crops has also increased the emissions of nitrous oxide.

\section{Carbondioxide $\left(\mathrm{CO}_{2}\right)$ releases linked to fossil fuel and deforestation.}

Over the past 250 years, deforestation, combustion of fossil fuels, and production of agricultural commodities such as rice and livestock have caused atmospheric concentrations of carbon dioxide (Darwin, 2001). CO2 releases in agriculture are related to land-use change (i.e. deforestation). The planet's major 
changes to land cover since 1750 have resulted from deforestation when forests and woodlands are cleared to make room for fields and pastures. The albedo of the affected area increases, which can result in either warming or cooling effects, depending on local conditions. Deforestation also affects regional carbon reuptake, which can result in increased concentrations of $\mathrm{CO}$, the dominant greenhouse gas. Land- clearing methods such as slash and burn compound these effects by burning bio-matter, which directly releases greenhouse gases and particulate matter such as soot into the air (Gallopin, 2006). The majority of onfarm $\mathrm{CO}_{2}$ emissions come from fuel combustion for heating farm building, drying of grains and machinery used for irrigation and intensive tillage. The use of fossil fuels in agricultural production emits greenhouse gases. Agricultural intensification mainly in developed countries after World War II has consumed heavy amounts of fossil fuels and other inputs, contributing significantly to GHG emissions (Glantz, et al.,2009). Increasing cultivation efficiency by moving to low- or zero tillage crop management practices, using more energy-efficient machinery, or reducing energy demand will reduce these direct $\mathrm{CO}_{2}$ emissions.

\section{Effects of climate change on agriculture}

Agriculture, however, is not only contributing to climate change, but is also affected by it to a large extent. Agricultural productivity can be affected by climate change through the following:

\section{Temperature increase}

Climate change leads to increase in annual temperature and rainfall (Baidya, Shrestha, and Sheikh, 2008.) Greenhouse gases absorb energy radiated from Earth to space and warm the atmosphere. According to IPCC (2007), increases in GHGs emissions have been associated with an increase in the mean global temperature of $0.3^{\circ} \mathrm{C}-0.6^{\circ} \mathrm{C}$ since the late 19th century. By the end of the 21st century, according the IPCC, GHGs emissions could cause the mean global temperature to rise by another $1.4^{\circ} \mathrm{C}-5.8^{\circ} \mathrm{C}$ (Darwin, 2001).

Higher temperatures provide a conducive-environment for the majority of insect pests. Higher temperatures lead to heat stress for plants, increasing sterility and lowering overall productivity. Higher temperatures also increase evaporation from plants and soils, increasing water requirements while lowering water availability. Higher temperatures affect both the physical and chemical properties in the soil. Increased temperatures may accelerate the rate of releasing $\mathrm{CO} 2$ resulting in less than optimal conditions of net growth. When temperatures exceed the optimal level for biological processes, crops often respond negatively with a steep drop in net growth and yield. Heat stress might affect the whole physiological development, maturation and finally yield of cultivated crops (Khanal, 2009). Temperature increases also have some direct consequences for animal productivity. Increased thermal stress will reduce animal eating and grazing activity, increase the mortality of animals, especially if kept in intensive livestock systems. (Mader and Davis, 2004). High temperature may also reduce the productivity of grasslands such that they are no longer sufficient for livestock (Mader and Davis, 2004 and Baidya et al., 2008). 


\section{Effect on crop yield}

Climate change is already affecting food security and it is expected to have even greater impacts in coming years (Glantz and Cullen 2003; Harris, 2009). According to Tinker, Goudriaan, Teng, Swift, Linder, Ingram and Geijn (nd) and Climate Change Science Program (CCSP) 2008), crop yield is negatively affected by changes in the climate. In developing countries, climate change will cause yield declines for the most important crops and South Asia will be particularly hard hit (Nelson, Rosegrant, Koo and Robertson, 2009). Food production in Africa could fall by half and in South Asia by 30 percent by 2030. In Africa, $25-42 \%$ of species habitats could be lost, affecting both food and non-food crops (Cribb, 2008). In developing countries, eleven percent $(11 \%)$ of arable land could be highly affected by climate change; there will be a reduction of cereal production in 65 countries and retardation of about sixteen percent (16\%) of agricultural GDP (Food and Agricultural Organization (FAO), 2007).

\section{Rising sea levels}

The Earth's oceans will expand, raising sea levels and reducing the amount of land available for agriculture. Sea temperatures are increasing, causing polar ice caps to melt, Arctic ice flows to retreat and sea levels to rise. Warmer oceans experience greater evaporation resulting in higher rainfall, which, together with rising sea levels contribute to coastal erosion and flooding (Lama and Devkota, 2009).

Rising seas contaminate coastal freshwater aquifers with salt water. Several small island states are already having serious problems with water quality, which is affecting agricultural productivity (Bryant, Smit, Brklacich, Johnston et al. (2000); Arnell, Cannel, Hulme, Kovats et.al. (2002). A rise in the sea level would result in an agricultural land loss due to flooding and salinization of surface water and ground water (Devereux and Edwards 2004). Higher seas also make communities more vulnerable to storm surges. In Nigeria, there are predictions of such surges (Ukudolo, 2010), and this is evident in the recent flooding in Kogi, Sokoto and Lagos States.

\section{Changes in pattern and extent of rainfall and evapotranspiration processes}

The warmer atmospheric temperatures observed over the past decades are expected to lead to a more vigorous hydrological cycle, including more extreme rainfall events, erosion and soil degradation. The increase in precipitations would probably result in greater risks of erosion and flooding (Fischer, Shah and van Velthuizen, 2002 and IPCC, 2007). Climate change would cause an increase in rainfall in some areas, which would lead to an increase of atmospheric humidity and the duration of the wet seasons (Chang, 2002 and Lama and Devkota 2009).

Change in climate affects the pattern and extent of rainfall and evapotranspiration processes which affect soil moisture storage, run-off, and water absorption by the plant. Both lack of and access to water might affect the different 
stages of plant production. Moisture stress during flowering, pollination, and grainfilling stage is harmful to most crops. Increased evaporation from soil and accelerated transpiration in the plants themselves will cause moisture stress (Loladze, 2002). Researchers have shown that increased concentration of CO2 in the atmosphere increases the likelihood of higher absorption of CO2 inside the plant through stomata during photosynthesis which provides carbohydrates for plant growth. Crop species vary in their response to $\mathrm{CO} 2$ according to their physiological class i.e. C3 versus C4 plants (Loladze, 2002). C3 and C4 are plant species that use rubisco to make a three-carbon and four-carbon compounds as the first stable product of carbon fixation respectively.

\section{Water availability}

The availability of water is fundamental to agriculture. The impact of climate change can occur through three major routes: drought - a lack of water for a period of time causing severe physiological stress to plants and animals; flooding - an excess of water for a period of time causing physiological and direct physical stress to plants and animals; and timing of water availability - when severe lack or excess of water does not occur but its availability through the year changes so as to no longer be suitable for current agricultural practices, crops or animals (Zierovogel, Nyong, Osman, Conde et al., 2004). When evaluating climate change impacts in areas typically using irrigation, the analysis of water availability must consider how the supply is buffered/stored for irrigation use. Irrigation demand is likely to rise in most regions with temperature increases due to increased evapotranspiration and possibly related decreases in rainfall at critical times during the growing season (Cline, 2008). More frequent droughts and increasing water scarcity may devastate large parts of the tropics and undermine irrigation and drinking water in entire communities of already poor and vulnerable people (World Bank, 2009).

\section{Changing season patterns}

In many places, growing seasons are changing, ecological niches are shifting, and rainfall is becoming more unpredictable and unreliable both in its timing and its volume (Olsen, 2007). This is leading to greater uncertainty and heightened risks for farmers, and potentially eroding the value of traditional agricultural knowledge such as when to plant particular crops (IPCC, 2007).

\section{Mitigation potentials in agriculture}

As a major source of GHGs, agriculture has much untapped potential to mitigate or reduce emissions (Smith, et al. 2007). Climate change mitigation involves actions that are intended to reduce the magnitude of our contribution to climate change. It includes strategies to reduce GHGs sources and emissions and enhance GHGs sinks (IPCC, 2001). Agriculture has the potential to change from being one of the largest GHG emitters to a net carbon sink, while offering options for mitigation. The solutions call for a shift to sustainable farming practices that build up carbon in the soil and use less fertilizer (Bellarby, Foereid, Hastings and Smith, 2008). 


\section{Sustainable agricultural practices}

The concept of sustainable agriculture endeavours to reduce chemical inputs and energy use in farming systems, in order to minimize environmental damage and to ensure longer term productivity (Rosenzweig and Hillel 1995). Sustainable agriculture helps to counteract climate change by restoring soil organic matter content as well as reducing soil erosion and improving soil physical structure (International Assessment of Agricultural Knowledge, Science and Technology for Development (IAASTD), (2008). Organic soils also have better water-holding capacity, which explains why organic production is much more resistant to climate extremes such as droughts and floods (Mae-Wan and Ching 2008). According to Bellarby et al. (2008); Niggli, Fliessbach and Hepperly, (2008), such sustainable agricultural practices include: organic farming/agriculture, biodiversity, better land management practices, use of biofuel/bioenergy, reduction of fertilizer use/ increase available soil nitrogen and reduce the need for synthetic fertilizers, composting vermicomposting, crop rotations that mitigate weed, disease and insect problems, soil conserving tillage which reduce soil erosion, integrated pest management (IPM), which reduces the need for pesticides by crop rotations, scouting, timing of planting, biological pest control, water conservation and water harvesting practices, planting of leguminous and cover crops etc.

\section{Organic farming}

Importantly, sustainable agriculture practices such as organic farming can mitigate climate change for example, it uses less fossil fuel based inputs and has a better carbon footprint than conventional agricultural practices. This is because conventional agriculture production utilises more overall energy than organic systems due to heavy reliance on energy-intensive fertilisers, chemicals, and concentrated feed, which organic farmers forego (Zeisemer, 2007). Organic agriculture performs better than conventional agriculture on a per hectare scale, both with respect to direct energy consumption (fuel and oil) and indirect consumption (synthetic fertilisers and pesticides), with high efficiency of energy use (Scialabba and Hattam, 2002 and FAO, 2007). Khor (2008) summarized the benefit of organic agriculture as regards climate change mitigation thus: organic agriculture holds an especially favourable position, since it realizes mitigation and sequestration of carbon dioxide in an efficient way. Organic production has great mitigation and adaptation potential, particularly with regard topsoil organic matter fixation, soil fertility and water-holding capacity, increasing yields in areas with medium to low-input agriculture and in agro-forestry, and by enhancing farmers' adaptive capacity (Basilio, 2000).

\section{Improved land management practices}

By applying improved land management practices (better soil fertility and water management, erosion control, reversion of cropland in industrial countries to permanent managed forests, pastures or ecosystems, biomass cropping, conservation tillage, etc.), the role of agriculture as a major carbon sink and as a 
compensating mechanism for agriculture's contribution to GHGs can be greatly enhanced. Land use management approaches can help mitigate global warming, these include planting trees, restoring degraded land, conserving natural habitats, and improving soil and fertility management (www.greenfacts.org/glossary/ def/deorestation.htm)

\section{Agrobiodiversity}

Agrobiodiversity, a term that encompasses all the plants, trees, animals, insects, microbes, pathogens occurring in agricultural systems plays a pivotal role in ecosystem and climatic challenges; it is a major building for food security and its conservation is essential if farming is to respond to challenges such as population growth and climate change (Spore 2010). Unfortunately, convectional agriculture has caused a dramatic reduction of genetic diversity within the animal and plant species typically used for food. About 7,000 different species of plants have been raised as food crops in the history of human agriculture, yet in part because of modern tendencies towards mass production, only fifteen plants and eight animal species are now relied upon for about $90 \%$ of all human food; as a result of this homogenization of the food industry, thousands of non-commercial animal breeds and crop varieties have disappeared, along with the valuable genetic diversity they possessed (http://www.sustainabletable.org/). Food and Agricultural Organization has identified the extinction of 300 out of 6000 breeds worldwide, with another 1,350 in danger of extinction (Food and Agricultural Organization (FAO), nd).

\section{Biofuel/bioenergy}

As concern about the impact of fossil fuels grows, energy production from agricultural crops has become a significant industry. This can help secure a safe supply of energy and mitigate climate change while creating development opportunity for the poor (Henry, 2009). Buchmann (2010) also observed that the sustainable use of bioenergy is possible and will play an important role in providing clean safe energy. Agriculture can also play a role in reducing the burning of fossil fuels. Up to 20 percent of fossil fuel consumption could be replaced in the short term by using biomass fuel. New liquid biofuels are made from crops or from agricultural and forestry residues and they produce less GHGs (Sundstrom, 2008). Energy can also be obtained from animal wastes, either by burning them directly or by first producing biogas then burning it. These renewable energy sources usually produce less GHGs emissions than fossils fuel (www.greenfacts.org/glossary/def/deorestation.htm).

\section{Criticism of sustainable agriculture}

One criticism of sustainable agriculture, especially organic agriculture, is that it cannot meet the world's food demands, primarily because of low yields and insufficient organic fertilizer. However, there is ample evidence to refute this argument. In general, organic yields can be broadly comparable to conventional yields in developed countries. In developing countries, organic practices can greatly increase productivity, particularly if the existing system is low-input. A recent study has found that organic methods could produce enough food on a global per capita basis to sustain the current human population, and potentially an 
even larger population, without putting more farmland into production (Bellarby et al. 2008). The researchers examined a global dataset of 293 examples, and found that on average, in developed countries, organic systems produce $92 \%$ of the yield produced by conventional agriculture (Bellarby et al. 2008). In developing countries, however, organic systems produce $80 \%$ more than conventional farms. Moreover, contrary to fears that there are insufficient quantities of organically acceptable fertilizers, the data suggest that leguminous cover crops could fix enough nitrogen to replace the amount of synthetic fertilizer currently in use (Bellarby et al. 2008).

\section{CONCLUSION AND RECOMMENDATION}

Climate change is now recognized as one of the most serious challenges facing the world - its people, the environment and its economies. It is believed that the changes in climate are attributable to emissions of GHGs that result from human activities. Agriculture, as one of the activities of man, emits a substantial amount of these GHGs; the major gases emitted by agriculture are carbon dioxide, methane and nitrous oxide. The amount of sources and sinks of these gases depends on land use and management of soils, crops, manures, livestock and energy.

In agriculture, the majority of on-farm carbon dioxide emissions come from fuel combustion for heating farm buildings and machinery, land use, deforestation etc. Similarly, the primary on-farm sources of methane emissions include enteric fermentation from ruminant livestock like cattle, sheep and goats and crop production especially rice production. Likewise, the primary on-farm sources of nitrous oxide emissions involve the production and application of nitrogenous fertilizers.

Climate change affects agriculture by raising temperature which affects crop and animal yield, changes in precipitation pattern, rise in sea levels which results in flooding and land salination.

Sustainable agriculture can contribute significantly to increased food production, as well as make a significant impact on mitigation of climate change; however, without appropriate policy support this improvement will wither away. A thriving and sustainable agricultural sector requires both integrated action by farmers and communities, and integrated action by policy makers and planners. Therefore the following recommendations were made:

(1) There is need for a systematic redirection of investment, funding, research and policy focus towards sustainable agriculture

(2) Agricultural policies that encourage farming by subsidizing safe and sustainable farm inputs should be encouraged

(3) Extension services should promote awareness-raising about sustainable agriculture and

(4) Sustainable agriculture should be integrated into all level of the education system. 


\section{REFERENCES}

Arnell, N.W.; Cannel, G. R.; Hulme, M.; Kovats, R. S.; Michell, F. B.; Nichollas, R. J.; Parry, M.; Livermore, M. J and White, A. (2002). The consequences of CO2 stabilization for impacts of climate change. Climatic Change. 53:413446.

Baidya, S. K.; Shrestha, M. L and Sheikh, M. M. (2008). Trends in daily extremes of temperature and precipitation in Nepal. Journal of Hydrology and Meteorology. 5(1): 108-121.

Basilio C. S. (2000). Organic agriculture: more farms, less hunger. Biotechnology and Development Monitor 42(24):65-72.

Bellarby, J.; Foereid, B.; Hastings, A and Smith, P. (2008). Cool farming: Climate Impacts of Agriculture and Mitigation Potential. Amsterdam: Greenpeace International.

Bryant, C. R.; Smit, B.; Brklacich, M.; Johnston, T.; Smithers, J.; Chiotti., Q and Singh, B. (2000). Adaptation in Canadian agriculture to climatic variability and change. Climatic Change. 45:181-201.

Buchmann, N. (2010). Future Bioenergy and Sustainable Land Use. Earthscan/WBGU.

Chang C. C. (2002). The potential impact of climate change on Taiwan's agriculture. Agricultural Economics 27 (2002): 51-64.

Climate Change Science Program, (2008). The effects of climate change on agriculture, land resources, water resources, and biodiversity. A Report by the U.S. Climate Change Science Program and the Subcommittee on Global Change Research. U.S. Environmental Protection Agency, Washington, DC USA.

Cline, W. R. (2008).Global Warming and Agriculture.

http://www.imf.org/external/pubs/ft/fandd/2008/03/cline.htm

Crib, J. (2008). Seeking answers to the food crisis. Partners in Research for Development. Nov.2008-Feb. 2009. 4-7.

Darwin, R. (2001). Climate change and food security. Agriculture Information Bulletin. 765-8. United State Department of agriculture (USDA).

Devereux, S and Edwards, J (2004). Climate change and food food security. In: F. Yamin and M. Kenbar (Eds.) Climate Change and Development. IDS Bulletin 35:22-30.

Fischer, G.; Shah, M and van Velthuizen, H. (2002). Climate Change and Agricultural Vulnerability. International Institute for Applied Systems Analysis. Report prepared under UN Institutional Contract Agreement 1113 for World Summit on Sustainable Development. Laxenburg, Austria. 
Food and Agriculture Organization (FAO), (nd). Biological diversity in food and agriculture: domestic animal genetic diversity. Retrived on 2nd August 2010 from http://www.fao.org/biodiversity/domestic_en.asp. r.

Food and Agriculture Organization (FAO), (2007). Adaptation to climate change in agriculture, forestry and fisheries: perspective, framework and priorities, Food and Agricultural Organization of the United Nations, Rome

Food and Agriculture Organization (FAO), (2008). Organic agriculture and climate change. Retrieved on August 10, 2010 from http://www.fao.org/DOCREP/005/ Y4137E/y4137e02b.htm\#89.

Gallopin, G. C. (2006). Linkages between vulnerability, resilience and adaptive capacity. Global Environmental Change. 16:293-303.

Glantz, M. H. and Cullen, H. (2003). Zimbabwe's food crisis. Environment. 45(1) 9-11.

Glantz, M. H.; Gommes, R and Ramasamy, S. (2009). Coping with a changing climate: considerations for adaptation and mitigation in agriculture. Food and Agriculture Organization of the United Nations Rome.

Harris, B. (2009). How climate change threats food security. People and Planet. http://www.peopleandplanet.net/doc.php?id=3482.

Henry, R. (2009). Plants Resources for Food, Fuel and Conservation. Earthscan.

Hohenstein, W. (2008). Challenges and opportunities for mitigation in the agriculture sector A U.S. perspective. US Department of Agriculture.

http://en.wikipedia.org/wiki/America meterological society

http://www.greenfacts.org/en/index.htm

http://www.sustainabletable.org

Intergovernmental Panel on Climate Change (IPCC), (2001). Climate Change 2001: Impacts, adaptation and vulnerability, GRID-Arendal.

Intergovernmental Panel on Climate Change (IPCC) (2007). Climate Change 2007: Synthesis Report. Contribution of Working Groups I, II and III to the Fourth Assessment Report of the Intergovernmental Panel on Climate Change [Core Writing Team, Pachauri, R. K and Reisinger, A. (eds.)]. IPCC, Geneva, Switzerland.

International Assessment of Agricultural Knowledge, Science and Technology for Development (IAASTD), (2008). www.agassessment.org

Khanal, R.C (2009). Climate change and organic agriculture. Journal of Agriculture and Environment. Review Paper. 10.100-110.

Khor, M. (2008). Food crisis, climate change and the importance of sustainable agriculture. Presentation at FAO Food Security Summit, Rome, 4 June 2008. 
Lama, S and Devkota, B. (2009).Vulnerability of mountain communities to climate change and adaptation strategies. The Journal of Agriculture and Environment. 10:65-71.

Loladze, I. (2002). Rising atmospheric CO2 and human nutrition: toward globally imbalanced plant stoichiometry? Trends in Ecology and Evolution 17: 457.

Mader, T. L. and Davis, M. S (2004). Effect of management strategies on reducing heat stress of feedlot cattle: feed and water intake. Journal of Animal Science 82:3077-3087.

Mae-Wan, H and Ching, L. L (2008). Sustainable agriculture: meeting food security needs, addressing climate change challenges. www.twnside.org.sg, www.biosafety-info.net.

Nelson, G. C.; Rosegrant, M. W.; Koo, J and Robertson, R (2009). Agricultural adaptation to climate change in the developing world: what will it cost? IFRPI Policy Seminar.

Nelson, G. C.; Rosegrant, M.W.; Koo, J.; Robertson, R.; Sulser, T.; Zhu, T.; Ringler, C.; Msangi, S.; Palazzo, A.; Batka, M.; Magalhaes, M.; ValmonteSantos, R.; Ewing, M and Lee, D.(2009). Climate change impact on agriculture and costs of adaptation. International Food Policy Research Institute .Washington, D.C.

Niggli, U.; Fliessbach, A and Hepperly, P. (2008). Low Greenhouse Gas Agriculture: Mitigation and Adaptation Potential of Sustainable Farming Systems. Rome: FAO.

Olsen, K. H. (2007). The clean development mechanism's contribution to sustainable development: a review of the literature. Climatic Change. 84:59-73.

Organic Consumer Association, (2008). Organic agriculture can help stabilize global climate change. Retrieved on August 10, 2010 from http://www.organicconsumers.org/ organic/stabalize062404.cfm

Organisation for Economic Co-operation and Development (OECD), (2008). Climate change mitigation -what do we do? Retrieved on 12/06/2010 from http://www.oecd.org/dataoecd/30/41/41753450pdf

Rosenzweig, C and Hillel, D (1995). Potential impacts of climate change on agriculture and food supply. Consequences. 1(2).46-55.

Scialabba, N.E.H. and Hattam, C. (Eds.) (2002). Organic Agriculture, Environment and Food Security. Rome: FAO.

Smith, P.; Martino, D.; Cai, Z.; Gwary, D., Janzen, H.H.; Kumar, P.; McCarl, B.A.; Ogle, S. M.; Mara, F. O.; Rice, C.; Scholes, R. J.; Sirotenko, O.; Howden, M; McAllister, T.; Pan, G.; Romanenkov, V.; Schneider, U. A and Towprayoon, S. (2007). Policy and technological constraints to implementation of greenhouse gas mitigation options in agriculture. Agriculture, Ecosystems and Environment. 118: 6-28. 
Spore, (2010). Dossier-Agrobiodiversity: thinking ahead. Spore magazine. 147:13-17.

Sundstrom, L. (2008). What challenges does agriculture face today. http://www. greenfacts.org/en/index.htm

Tinker, B.; Goudriaan, J.; Teng, P.; Swift, M.; Linder, S.; Ingram, J and Geijn, S (nd). Global change impacts on agriculture, forestry and soils: The programme of the global change and terrestrial ecosystems core project of IGBP. http://fao.org/ docrep/w5183e/w5183eof.htm.

Ukudolo, E. (2010). Nigerian Compass Newspaper. http://www.compassnewspaper.com/NG/index.php?option=com

World Bank (2009). Agriculture for development, Overview. Retrieved on July 26 2010 from http://siteresources.worldbank.org/INTWDR2008/Resources/27950871192111580172/WDROver2008-ENG.pdf

World Bank, (2008). Agriculture for development policy brief: adaptation and mitigation of climate change in agriculture: World Development Report 2008.

http://siteresources.worldbank.org/INTWDR2008/Resources/Brief_AdptMitC limateChng_web.pdf

World Resources Institute (WRI), (2007). Agriculture and climate change: greenhouse gas mitigation opportunities and the 2007 farm bill. WRI Policy Note: climate and agriculture. No.2

www.greenfacts.org/en/agriculture-iaastd/figtableboxes/figure-sr-cc2.htm Zeisemer, J. (2007). Energy Use in Organic Food Systems. Rome: FAO.

Zierovogel, G.; Nyong, A.; Osman, B.; Conde, C.; Cortex, S and Downing, T (2004). Climate variability and change: implication for household food security. AIACC Working Paper. No. 20. 